\title{
Sobre els orígens de la novel.la
}

\author{
JÚLIA BUTINYÀ
}

(UNED)

Per a Jeroni Miguel

Una inquietud es pot destriar entre les que, de nou encuny, assaltaven els homes cultes entre el segle XIV i XV: la inquietud que gira al voltant de les subtils relacions - conjunció o disjunció- de la ficció i la història. 'Havent atès Garin els nous aspectes socials i de la vida civil que germinen a causa de la introducció de l'humanisme, diu que l'interès envers la història fou conseqüència natural del sentit concret de la vida, de la valoració de l'activitat humana (1986: 133). I, amb fragments de Valla i de Poliziano, en deixa mostra a través de dos conceptes que ens interessaran tot seguit: el valor dels exemples i la persecució de la veritat (ib. 134).

Quant a les lletres catalanes, a fi de localitzar aquestes primeres estrebades, trobem uns símptomes clars a la polèmica del Griselda (Butinyà 2002 b), on discuteix Metge amb Petrarca i Boccaccio sobre tots dos conceptes suara esmenats. Ja és sabut que el moment més ferm i pur al llarg del curs del moviment a les lletres catalanes va concretar-se a l'entorn de Metge i dels seus amics a la Cancelleria de Barcelona; per tant, en principi sembla difícil de rastrejar-lo fora del Griselda, que, encara que afecta la idea exemplar i l'autenticitat, així com el tractament de la prosa $i$ àdhuc la manera de narrar o l'elevada concepció de la literatura profana, no fa el pas cap a la invenció de la novel·la. Metge, més decantat cap a la filosofia que cap a la ficció, amb tot, hi toca molts aspectes literaris, els quals - com anirem veient - tenen continuació i desenvolupament en un segon moment, en el qual ens situem ací: cap a la segona meitat del XV, etapa que, des del punt de vista cultural, ens remet a Nàpols; ${ }^{2}$ així com seguiran desenvolupant-se al tercer moment, el valencià.

I a la cort napolitana, que fou el moment més brillant des del punt de vista cultural gràcies al mecenatge reial, com es fa palès per les obres que són dedi-

' Com tot el que s'esdevé en aquest canvi de segle, pot tenir l'alenada classicista al darrere; potser en relació amb la primera introducció d'idees classicistes (en concret, de Sal-lusti, com veurem). Però no ens detindrem ara en aquest aspecte, ja que en aquest treball n'estem fent tan sols una primeríssima aproximació.

${ }^{2}$ Des de la història de la cultura, Eulàlia Duran en tracta àmpliament (2004, 40-41, 381-397 passim), tot i que sense distingir els esglaons del moviment humanista sinó com el primer pas cap el Renaixement. (Vegeu la nota 52 infra). 
cades al Magnànim, al seu fill Ferran I i al fill d'aquest, Alfons (Duran 2004: 385), és on qualla la nova historiografia de la cultura catalana, a partir de l'alè renaixentista que exercitaren a Roma el cardenal Margarit i Jeroni Pau en temps dels Borja (Batllori 1995: 120-125). No és gens forassenyat, doncs, d'intentar esbrinar-hi les relacions amb el món de la ficció.

L'estudi de Duran, a l'apartat sobre la història dins del capítol L' humanisme català i la cort de Nàpols, ens situa molt propers a l'angle oportú per tal d'observar la conjunció esmentada. Primerament, s'ubica dins la retòrica, per tant de les humanitats, i s'hi explica com la història formava part del bagatge cultural de nobles i eclesiàstics, a què accedien els notaris, sobretot com a cronistes o dietaristes. Segons Duran, «el retrat robot d'un notari del Renaixement estava en òptimes condicions per convertir-se en un historiador» (ib. 516). Així, la història, «les discussions sobre la seva essència, el seu mètode, l'anomenada ars historiae, va ser un dels temes controvertits per excel-lència. Era la primera vegada que es quiestionava» (ib. 387); per exemple, a la pàgina següent, veiem com es plantejaven si havia de tractar també del present $i$ «si eren lícites les ficcions poètiques com, per exemple, les arengues o discursos posats en boca dels personatges, i la utilització de llegendes». ${ }^{3}$

La doctrina al respecte l'exposà Lorenzo Valla a Nàpols el 1445, tot prestigiant aquella ciència. En esguard a les qualificacions aristotèliques de la Poèti$c a$, ell assegurava la poesia al damunt de la filosofia «perquè era més incisiva, molt més capaç de moure els ànims gràcies a l'estil» (ib.), ${ }^{4} \mathrm{i}$ intentava mostrar que la història, com aquelles dues (filosofia i poesia) tracta de conceptes universals. Bo i seguint Ciceró i Quintilià, considerava que té una funció moral i ensenya mitjançant fets vitals. «I va fer aleshores el salt qualitatiu: la història, pel seu caràcter exemplar, no només era un discurs retoricopedagògic, sinó que tractava de matèria universal», ib. $389 .^{5}$

A continuació, Duran es demana pel ressò de les teories de Valla i considera que, almenys en els pròlegs, es reflectí la seva problemàtica; ${ }^{6}$ ara bé, al meu entendre, en el camp de la creació literària també cal comptar que haguessin tingut un reflex. ${ }^{7}$ I de fet, a les lletres catalanes es constata ben bé al pròleg del III

${ }^{3}$ Cal anotar ací les excuses de l'autor del Curial al començ del III llibre «per ço com en aquest haurà algunes transformacions e poètiques ficcions, scrites no en la manera que a la matèria se pertany, mas axí rudament e grossera, com yo hauré sabut fer» (III, 13).

${ }_{4}$ També tractarà Duran de la polèmica en relació amb la filosofia d'Ausiàs March - el famós humanista emulador de Petrarca, segons la fama del segle següent-, tot i pertànyer al món literari (ib. 573-591).

5 «Al costat dels temes universals abstractes de la filosofia, al costat dels personatges universals creats per la ment del poeta, hi havia el món dels temes universals "vers" de la història, expressats a través de personatges o fets verídics», ib. 389-390.

"Aquestes discussions arriben a veure els evangelis com «un cuento verdadero» (en paraules de Martí de Viciana, ib. 391). Coses que no fan més que avalar el triomf de la història.

7 Així doncs, proposem que aquest clímax no es pugui desconnectar del món literari, sobretot en un cas concret: la primera manifestació de la novel-la, precisament de la novel.la cavalleresca, tan lligada als fets reals. I si des de la descoberta, es va proposar la ubicació del Curial al cercle napolità - cosa que s'ha anat rubricant per motius linguíístics i des de la història (segons recullo a Butinyà 2001), sense acceptació definitiva, però-, ara hi afegiria la coherència ideològica i temàtica d'acord amb aquestes inquietuds. 
llibre del Curial, ja esmentat. En aquesta novel-la - lligada tradicionalment al cercle napolità i per a la qual he mantingut l'autoria d'un notari, mossèn Gras, cosa que lligaria la novel-la molt directament al Magnànim-, ${ }^{8}$ observem que la seva retòrica, tan fermament treballada al llibre III, des d'aquest pròleg anuncia el triomf de la poètica, de la mà de la història, i aporta poc després - -al passatge mitològic - importants principis filosòfics, com ara la idea d'ensenyar i aconsellar, amb paraules nogensmenys de l'aristotèlica Ėtica Nicomàquea. Val a dir que, si per a Valla la història es movia dins l'àmbit de l'oratòria, per a aquest autor la poètica es mou juntament amb la filosofia i la història. Sobretot comptant amb l'eficiència moral, segons insisteix, des del pròleg inicial, tot al llarg de l'obra.

L'obra era exemplar quant als protagonistes —els seus actes ho havien de ser, en això consisteix tota l'escalada dels tres llibres cap a la virtut i queda segellat rere els somnis al-legòrics de Bacus i de Fortuna, repectivament per a Curial i Güelfa- . I, alhora era també exemplar quant a l'estil, sobre el qual es reflexiona al pròleg del III llibre i es rubrica al somni al-legòric d'Apol-ló. Val a dir, l'autor és ben conscient que les poètiques i reverenciades ficcions al-legòriques ja eren cosa tocada de mort -bé que encara les havien conreades Petrarca i Boccaccio, o més a prop el marquès de Santillana-; ho acusa amb plasenteria i, si hi recorre, és per tal d'aprofitar l'efecte i la moda, però girant el seu joc amb humor i distanciament, de manera alliberada i rompedora, que inaugura un nou estil. ${ }^{9} \mathrm{D}$ 'altra banda, també l'escriptura de Metge era, mitjançant totes les formes d'humor i molt especialment la ironia, un revulsiu contra la mitologia morta o una burla de la moda al.legòrica ja démodée; no havia fet altra cosa al Libre de Fortuna e Prudència. ${ }^{10}$

I si anem ara al concepte d'història de Bruni —qui escriu sobre la ciutat de Florència, havent precedit els criteris immediatament anteriors de Salutati-, veiem que mostra un desig de depuració d'elogis retòrics, el qual també es podria contraposar al desig d'autenticitat del relat del Curial, condemnant les lloances vanes i interessades; " són uns mateixos cànons, aplicats a la creació literària. «Una cosa es la laudatio y otra la historia: 'la historia es verdad' (historia sequi veritati debet)», Garin 1982, $40 .{ }^{12}$ I els bons autors s'havien d'arrenglerar amb aquests criteris d'exactitud i rigor.

8 Vegeu Butinyà (2001: 211-334); la hipòtesi fou presentada primerament a la Reial Acadèmia de Bones Lletres de Barcelona: Sobre l'autoria del "Curial e Güelfa", "Butlletí de la Reial Acadèmia de Bones Lletres de Barcelona» XLI (1987-1988), 63-119.

${ }^{9}$ Ho tracto en Algunas consideraciones sobre poética medieval en el Humanismo catalán, «Revista de Poética Medieval», 12 (2004), 11-52.

10 Veg. la tesi doctoral de Miquel Marco, «Libre de Fortuna e Prudència». Estudio de las fuentes literarias y edición critica (UNED 2004).

"A això responen totes les intervencions i discurs d'Apol-ló referent a teoria literària (III, 83, 86-90). Referint-me al lent i espars procés dels inicis de l'humanisme, comento, a Un par de notas sobre el humanismo catalán, en Homenaje a M. José López de Ayala, UNED, en prensa: «Al principio, incluso, se trataba de ideas sueltas comprendidas en profundidad; incluso de cambios de actitudes, como puede quizás verse en lo diferente del reverencialismo medieval y la admiración humanista». Observem, però, que la diferenciació deriva en profunditat d'un desig d'autenticitat.

12 En la línia reprovada es trobaria encara el Marquès de Santillana, la retòrica del qual he contraposat a vegades a la de l'autor del Curial, ja que la Comedieta de Ponça és expressiva del primer extrem, mentre que la novel-la catalana ho és de l'altre; aquesta admet tanmateix la ironia, que és de- 
«Por poco que te esfuerces te será fácil componer un libelo o una epístola, pero escribir una historia, que contenga la exposición ordenada de una pluralidad de cosas diferentes, y sobre todo que explique las razones de las decisiones adoptadas, y juzgue las cosas acaecidas, es propósito tan riesgoso de declarar como difícil de cumplir» (Bruni, cit. de Garin, ib.). De la mateixa manera s'ha elaborat el Curial, des de la ficció, amb cost i sobretot risc, segons al-lega l'autor; per tant, no tracta tant de realisme literari esteticista com d'afany de veracitat; cosa que coincideix amb el que reclamava Boccaccio al pròleg de la IV Jornada decameroniana, on exposa i defensa amb les dents la seva retòrica, malgrat els atacs a què s'hi arrisca.

Des d'aquesta perspectiva cobren relleu i carta de noblesa les iniciatives d'estudi sobre el reflex de la realitat en el Curial; és a dir, les anomenades identificacions - amb què sovint ha intervingut la crítica, generalment amb cert aire festiu - o el possible paral-lelisme amb els fets reals, sigui rere un posat d'humor sigui rere l'ombra aristocràtica dels fets del passat, llegendaris o històrics. Car aquests recursos es troben al bell mig de la ficció i la realitat, al punt que en aquell encara primerenc humanisme discutien aquestes coses; són molt serioses, a més, car són les peces amb què s'està construint la primera novel.la moderna.

Seguint l'estudiós italià entorn de l'obra sobre Florència de Bruni, «el Humanismo había sido como la luz después de setecientos años de tinieblas; sin embargo, supo reconocer el valor del Medioevo y lo buscó en los orígenes de la ciudad» (ib). Vet ací, un altre comentari que, des de la creació literària i no la històrica, és idoni per a l'autor del Curial: obra que irromp amb luminositat sense anul-lar el passat, el qual s'hi manté viu, rescatat des dels orígens de la Corona d'Aragó, i amb el qual s'identifica l'heroi. En certa manera, també ho havia fet abans Metge, en el seu diàleg, on compta amb el passat; en el seu cas, amb el cabdal de la pròpia tradició - sobretot, el lul-lià, el qual considera valuós i amb el qual sovint s'identifica-.

Sobre la importància dels matisos d'actitud o tarannà —que, de fet, acabaran donant consistència a un canvi ben dràstic - he comentat recentment pel que fa a la tradició, que «el confusionismo - la falta de percepción para distinguir los talantes, es decir los matices entre lo que era válido de la época anterior y lo que ya no valía - es lo que denunciaba Metge en la doctrina de Petrarca y le hacía cerrar Lo somni con una mezcla tremenda de consejos humanistas y egoístas, incomprensible desde otro punto de vista (370, 20-27, ed. Riquer), que dejaba al autor completamente desconsolado.» ${ }^{13}$ I això, aquest respecte envers el passat i alhora el desig d'aprofitament i no de trencament, els donava un aire de continuïtat, que a vegades ha fet negar el moviment, ha desconcertat o ha fet impre-

formadora dels fets però és una actitud exigent i exacta quant a rigor o mirall dels fets, que exclou l'actitud d'adulació. Vegeu La "Comedieta de Ponça» i el «Curial e Güelfa» frente a frente, "Revista de Filología Española», LXXIII (1993), 295-31 1, i més recentment Butinyà 2001 al capítol de la gènesi estructural (149-210), on s'analitzen els nous elements literaris i la funció que exerceixen.

1. Sobre las versiones de clásicos catalanes: el "Curial e Güelfa" y "Lo somni", en La traducció literària en l'època contemporània, coord. per A. Camps, Universitat de Barcelona 2005,55 . 
cisos els seus límits; més encara quan s'afegeix al damunt d'una introducció que he qualificat de suau (nota 11 supra). Perquè Metge, per bé que es burli de les deesses tradicionals en un debat a l'antiga usança, en Lo somni introducix les figures d'Orfeu i Tirèsies, plenes de vida. No sols és un moviment de transició, amb figures mixtes de tota mena a les nostres lletres, sinó que els mateixos capdavanters presenten dues cares que cal distingir ben bé.

D'altra banda, els gèneres es renovaven amb el canvi de mentalitat, en consonància no sols amb l'exigència dels autors sinó també amb la demanda de l'audiència; és per això que, a l'escalf del nou moviment, reben una nova empenta, una direcció diferent a la secular, cosa que no cal confondre amb cap tipus d'il-luminació lligada a un moviment sortit del no-res. Tot era compost de petites gotetes i es movia en difoses onades. No debades la biografia comença amb Mussato - a qui cal comptar entre els introductors de la teologia poètica--, fet que s'acompanya d'un nou interés característic per l'home, així com va d'acord amb la tirada pel gust pels retrats en aquesta època (Garin 1986: 229). A l'igual, canvien els exemples i una Griselda renovada - bé que aparentment s'assembla molt a les santes antigues - desplaça l'hagiografia tradicional (Butinyà 2002 b); punt que ens mena a la idea de virtut, també renovada, comanada ara sobretot per una vida, a més d'intel-lectual, activa, autàrquica, tan diferent que no hom fa escarafalls d'arribar al suïcidi (Garin 1986: 99-109).

Darrere d'aquests aspectes podríem anar anotant fets i detalls del Curial, on, per exemple, la veritable heröna en la virtut que assenta la novel-la, l'amorosa, se suïcida per amor fent manifestació de cristianisme. Extrems, doncs, que si no es veuen sota aquesta dinàmica de canvi no poden tenir cap explicació. I si anem al Magnànim, se'ns facilita encara més aquell clímax de conjunció amb què hem començat $i$ anem resseguint, ja que trobem a la seva cort el mateix Valla; tot i que podríem remuntar a la seva relació amb Bruni, amb qui s'escrivia abans d'anar a Itàlia (Voigt, I, 459).

Cal també esmentar l'ascendència de l'alè epicuri, que sembla que s'estén com una taca d'oli ran del De voluptate de Valla (1431), i que no havia de deixar d'afectar la manera d'escriure i la concepció historiogràfica. Obres amb la voluntat de ser edificants no eren ja obligatòriament tractats o renys, sinó lectures agradables i amenes, i deien les coses desagradables de manera plaent. Fill ben natural de tot això pot resultar, doncs l'experiment del Curial, obra nova o diferent, d'alta sensibilitat i voluptuositat, d'acord amb l'elegància dels sentits i de l'antiguitat. ${ }^{14}$ Bé ho manifesten les deesses de l'amor a la important i profunda - a més de divertida- exposició mitològica, ja esmentada, del llibre III, les

${ }^{14}$ Observem, per exemple, un fet que pot tenir diferents explicacions: la coronació del llorer d'Apol-ló al cavaller protagonista, entre la burla i la realitat, pot al-ludir - fora del mateix personatge literari, que seria la visió menys interessant—, al Magnànim —que feia versos-o bé —o alhoraa la mateixa obra. Amb això darrer, l'autor estaria complint el paper de Màrsias, ja que per arribar a la perfecció ha de passar per l'agonia. I ell no lloava els versos reials - com feia Santillana, per exemple-, però en deixava constància; mal pas que per a un servidor del Magnànim era inclòs al fet de no escriure amb llagoteria, sinó com les Pièrides, segons diu al pròleg del III (Butinyà 2001: 279283 passim). I, fent un salt comparatista, si pot semblar estrany el fet de coronar l'autor del Curial la seva poètica, pensem a un cas semblant i més proper, ja que el signe llorejat s'ha vist darrera el 
quals hi mostren a Fortuna la manera d'aconseguir les coses, amb suavitat, pregant i no exigint i cridant (III, 54).

Del Curial estant no costa gaire de fer el pas cap al Tirant, pas que des del punt de vista de la cavalleria és claríssim i sense cap sotrac - al ritme de la descomposició d'aquesta institució-; ${ }^{15}$ arribant àdhuc al Quixot, com un tercer esglaó des de l'admiració a la mitja burla i la burla completa. Doncs així mateix fan un esglaonament claríssim els components narratius des del punt de vista estrictament literari; el desig de complaure i atreure un lector va adoptant noves llibertats, nous recursos i maneres. ${ }^{16}$ Ara bé, entre Curial-Tirant, així com entre Griselda-Curial no hi ha nexes materials, intertextualitats ni documents, només ens és lícit enfilar els fets literaris expressats en una mateixa llengua i mostrar-hi una gradació, sense pretendre l'evidència del lligam, però sense negar una continuïtat real.

El clímax, però, és el mateix i es reconeix una línia ideològica amb vigència al llarg del moviment, com ho proven els punts d'anàlisi concrets. ${ }^{17}$ Per exemple, podem seguir una idea - fins a quin punt va constituir un dels ressorts de l'humanisme català?- - que s'ha detectat en un document del Cerimoniós procedent de Sal-lusti, ${ }^{18}$ la qual arriba a convertir-se en tòpic: són necessaris bons escriptors per tal de donar vitalitat a les gestes. Idea que es troba també a les lletres castellanes o bé es recull a la Storia fiorentina de Varchi, ${ }^{19}$ però que va apa-

pseudònim de Lorenzo Gracián per part del jesuïta que també firmava com Baltasar (Małgorzata Anna Sydor, Los hermanos Lorenzo y Baltasar Gracián, en Estudios Hispánicos", 12, Miscelánea de Literatura española y comparada. Homenaje a Roberto Mansberger Amorós, coord. per A. August Zarębska, J. Butinyà, J. Ziarkovska, Universidad de Wrockaw, en premsa).

is No ha d'estranyar que l'obra no sigui de lectura unívoca o rectilínea si estem dient que ja no és una obra medieval; bé que tingui elements —com ara l'admiració de la cavalleria-medievals, però mai no medievalitzants. En la n. 21 (infra) fem un contrast amb el Tirant, el qual és favorable al Curial a causa del fi sentit humanista.

${ }^{16}$ Em remeto a les conclusions de Butinyà 2001, en especial, 339-340, 346. Es fa especialment curiós tenint com a referent el Quixot, on es reconeix el mateix tarannà literari de l'autor del Curial. Per tant, no cal el contacte directe: el clímax, l'hàbitat, l'evolució, així com els trets genètics als individus, generen trets semblants.

${ }^{17}$ Ho he analitzat repetides vegades des del punt de vista de la consciència lingüística, dins de les investigacions portades a terme al Projecte d'Investigació sobre «L'adquisició de la consciència lingüística europea», dirigit per Emma Martinell. Així, a La conciencia lingüística en las letras catalanas de la Edad Media: del campo histórico y del filosófico a la ficción, en E. Martinell y $\mathrm{M}$. Cruz (eds.): La conciencia lingüística en Europa. Testimonios de situaciones de convivencia de lenguas (ss. XII-XVIII), Publicacions de la Universitat de Barcelona 1996, 79-134; Convivencia de lenguas en "Curial e Güelfa» $y$ "Tirant lo Blanch», "Butlletí de Ia Reial Acadèmia de Bones Lletres de Barcelona» XLIII (1993), 333-346; Actituds culturals davant l'encontre lingüístic: el "Tirant lo Blanc" $i$ el "Curial e Güelfa", en Oriente y Occidente: actitudes culturales ante el encuentro lingüístico, Reial Acadèmia de Bones Lletres de Barcelona, 1992, 35-46.

${ }_{18}$ Historiador que així mateix m'ha semblat poder reconèixer en el parlament del rei Martí (1406), procedent del pròleg de Bellum Iugurthinum. (Vegeu Un par de notas sobre el humanismo catalán en Homenaje a la profesora M. ${ }^{a}$ José López de Ayala, UNED, en premsa).

19 «Es certísimo que, si sucediera que aquellos que hacen cosas grandes y se fatigan para que los demás puedan descansar no tuviesen quien escribiese sus acciones y proezas, y no digo ya quien las ilustrase y esclareciese, quedarían sus trabajos como vanos y poco menos que perdidos, y ellos yacerían para siempre en la sombra» (Garin 1986, 138). Comentari que es pot posar de costat al de l'autor del Curial tancant el pròleg del III llibre quan es plany que Curial no compti amb bons 
reixent en diferents punts i moments de les manifestacions humanistes a les lletres catalanes.

Voigt indica que Porcello Pandoni fou el primer reporter en el camp: «Infatti il re lo spedì al campo de' veneziani, soi alleati, il cui condiottiere Giacomo Piccinino combatte nel 1452 e nel 1453 contro Francesco Sforza. Il Porcello è il primo letterato, che sia stato accreditato per far da relatore storico al campo» (I, 1988: 493). Això l'acosta significativament al Curial quan distingeix entre els qui narren el que han sentit i els qui ho fan sobre la informació rebuda, al somni del Parnàs (III, 75); ara bé, la retòrica de lloa de Pandoni és oposada a la del $\mathrm{Cu}$ rial; per tant, encara que tractessin o no tots dos de la mateixa figura, el Magnànim, les obres resulten absolutament diferents.

Tot i així, l'obra de Porcello Pandoni no va destacar del conjunt dels Triumphus reials, malgrat que rebé de les mans del rei la corona de poeta, orador i historiador (Voigt, I, 493). Ara bé, com a possible ressò —contacte o record-cal remarcar la semblança entre aquest nom i Melchior de Pando, el mentor de Curial - a part que tota la crítica entengui que aquest ancià amaga el mateix autor--, especialment tenint en compte que aquest juga sovint amb la fonètica i l'onomàstica.

Tampoc no es podia avenir l'autor del Curial als escrits de Bartolomeo Facio o Antonio Beccadelli, el Panormita, que també voltaven entorn del mecenes. Els escrits del primer eren "una glorificazione per mezzo delle arti della parola» (Voigt, I, 489) per tal d'immortalitzar el rei; el segon, bé que assolí més fama i era més lleuger, no deixa de fer-ne un retrat al gust humanístic, fora de la realitat i dels signes que comporta aquesta, com ara l'humor, la ironia i sobretot la facultat de ser eficient; com ho són els exemples de ficció, no sols versemblants, ans autèntics. Paper que, per contra, fa seu el novel-lista, deixant clar al començament del III llibre que Curial no ha tingut «poeta o orador» a l'altura de la seva talla (III; 16), idea que acabem de veure amb ascendència en Sal-lusti. I idea que tot just era un tòpic aplicada al Magnànim, encara que van dedicar obres al rei grans humanistes que no havien estat mai a la seva cort: Leonardo Aretino, Poggio, Decembrio o Giorgio da Trebisonda; ${ }^{20}$ alhora que el rei despenia grans sumes per a atreure's gent de nivell. Però, segons afirma Voigt, «non furono tanto queste spese quanto e assai più il personale interesse che egli mostrava per la letteratura e la protezione che accordava ai letterati, ciò che gli valse la gloria di splendido mecenate» (o. cit., I, 498).

L'apogeu de la història va de la mà amb el dels historiadors; seguim amb Duran: «A imitació de les històries clàssiques, les històries humanístiques s'ompliren de diàlegs i arengues versemblants, de poètiques ficcions, de llegendes, de mites. Tot servia per a embellir o consolidar els raonaments. La veritat podia

\footnotetext{
escriptors que cantin els seus actes ( $i$ això, al marge de la ironia que hi hagi en referència envers una realitat, ja que ha dit poc abans que ell és indigne però que farà el que bonament pugui).

20. L'estudi de Voigt esmenta altres vides del rei Alfons, com ara la de Manetti, «che doveva corere parallella con quella di Filippo di Macedonia» (I, 497), però tot plegat són honorífiques o bé perseguidores d'agradar i lloar. Justament el que es condemna en el Curial, en la intervenció mitològico-al-legòrica amb citació aristotèlica (III, 70; sobre aquesta cita i la confirmació que no és cap badada, com havia mantingut la crítica anterior, vegeu Butinyà 2001, 112-117).
} 
quedar molt amagada o manipulada. (...) Els humanistes historiadors eren persones que coneixien una art, la de l'anàlisi dels fets, i la sabien presentar de manera convincent. Això els donava una arma poderosíssima i els prínceps veieren en ells els perfectes creadors de la fama, de la seva fama, de la fama de les seves gestes» (o. cit., 471). Comentaris que tornen a apropar el món literari i el de la història, aleshores molt veïns quant a maneres de fer; $i$ en detalls concrets, com el suara esmentat de la fama, tornen a fer familiars el món del Curial, on la fama literària és un motiu molt i molt poderós, ja que afecta directament a la mort de la protagonista en amor, Càmar, en un passatge que amb el rerefons de l'Eneida il-lustra el somni d'Apol-ló, somni en el qual el déu assenta que no s'han de deformar els fets reals (Butinyà 2001: 161 passim). Observa Lida de Malkiel que no passa el mateix en el Tirant lo Blanc, on la fama segueix el criteri ascètic propi dels velles temps (La idea de la Fama en la Edad Media castellana, Fondo de Cultura Económica, Madrid 1983, 267-269); mentre que en el Curial la fama del protagonista és un clamor progressiu, com marca el pròleg al III llibre (veg. Un par de notas sobre el humanismo catalán, en Homenaje a M. José López de Ayala).

A tall de resum podem dir que en el període del Magnànim destaquen aquests dos aspectes propis de la historiografia humanista: la reflexió crítica i la biografia panegírica. ${ }^{21}$ Dins el món on bullien aquelles idees i discussions, es va generar una obra mig-exemple, mig-retrat, responent a una retòrica planera i veraç; no tindria sentit deslligar excepcionalment el fet històric del literari en aquest cas. D'altra banda, l'autor que hem proposat per al Curial - mossèn Gras-, notari, va ser ambaixador a Tunis i va traduir amb un estil humanístic l'obra cavalleresca de la Mort Artu.$^{22}$ Encara, estava al servei del comte d'Ischia, ${ }^{23}$ casat amb Antonia d'Alagno, germana de Lucrezia, famosa pel fet que hom la considerava - tot i que podria ser molt bé que tan sols fos vox populi-l'amant del monarca, dona d'influència poderosa - cosa que no ha negat ningú-.

Dins la novel-la del Curial, hi ha un munt de situacions que responen a la conjunció que seguim. Com ara, el passatge de Ponça de la ficció, que considerem una rèplica mig burlesca mig oposició a la versió de Santillana, car l'autor català assegura fer literatura auténtica - limitant-se a daurar uns fets no tan brillants-; i així, trobem marejats els navegants de la ficció, segons va succeir al fet real, cosa que potser fou una de les causes del desastre. ${ }^{24}$ I cal remarcar que

21 Vegeu Batllori 1995, 119-124. Seguidament, dóna raons de la manca del vessant panegíric a Catalunya, al segle $x v$, ja que el moment d'esplendor literari i cultural era inclinat cap a València, on no hi havia tradició historiogràfica $i$ les condicions curials no eren les pròpies per generar aquest tipus d'escritura. Així doncs, de la mateixa manera que ací no era adequada la generació d’aquest tipus d'escriptura històrica, al cercle napolità li és adient la novel-la del Curial.

22 Es tracta de La tragèdia de Lançalot (Riquer, 1964: 721-723, qui la fa propera al Curial).

${ }^{23}$ La colònia catalana d'Ischia, desconeguda pràcticament, va assolir fermesa, segons atesta la crònica del Panormita, $\mathrm{i}$ àdhuc se $\mathrm{n}$ 'ha volgut rastrejar la petja lingüística (Història de la Llengua Catalana II de Nadal-Prats, ed. 62, Barcelona, 1996, 87-88).

${ }^{24} \mathrm{El}$ passatge on Curial venç prop de Ponça, després d'un encontre naval, pot estar amarat d'ironies pel que fa als esdeveniments que l'envolten: tractament a la semi-presó en què el posen, acord de diferents nacionalitats per a la solució, etc. (III, 26-31), les quals bé mereixen l'atenció dels historiadors. 
l'episodi no es refereix tant al fet bèl-lic com al polític, que és el que aquests humanistes valoraven. "La historiografia humanística del segle XV continua interessant-se pels fets bèl-lics, però amb una major atenció per l'estratègia militar, per la diplomàcia, per la política» (Duran 2004: 475). Recordem que és l'època tot just en què s'ha situat el canvi cap a la historiografia moderna.

Cal fixar-se també en un comentari de l'autor al pròleg del IIl, ja que l'obra s'ha anat fent més i més complexa a mesura que ha anat avançant, cosa que li obliga a aclarir, abans d'entrar al terreny de les poètiques ficcions, que aquest llibre «és algun poquet pus intricat que-Is altres primers», III, 13. Em demano fins a quin punt respon a un programat ensinistrament de l'autor envers el lector, o fins a on es tracta d'una obra que ha anat creixent amb el pas del temps i al caliu dels fets històrics. I si s'ha plantejat aquella primera posició - ben lògica des del desenvolupament literari, així com des de la perspectiva del camp de les virtuts i de la reprensió cap al gran rei- ${ }^{25}$ tenint al davant aquests plantejaments teòrics i la història com a motor darrere l'obra literària, cal tenir en compte que potser hagi esdevingut el que en altres obres literàries de l'època: que s'hagi anat produint al caliu dels fets reals i dels esdeveniments.

Vegem el que diu Duran del poema de Lepant: «Una crònica d'un fet coetani ha estat considerada normalment com un text historiogràfic, sobretot quan pretén donar una relació verídica dels esdeveniments narrats. Però quan aquesta relació és presentada en forma poètica o ornamentada amb elements de ficció, el text en qüestió entra també de ple en el camp de la literatura», op. cit., 557. Al Curial, però, esdevindria a l'inrevés, es tractaria d'una obra literària que s'hauria d'interpretar a l'ombra dels fets històrics. ${ }^{26}$ Tot i les diferències sembla vàlida la comparació, almenys metodològicament; així, aquell poema, de fet, s'inscriu de ple en les anomenades Caroleidas en honor de l'emperador Carles V i respon, bé o malament, als mòduls estètics del Renaixement; mentre que les exaltacions del Magnànim es movien encara dins l'humanisme, almenys pel que fa als autors que en el seu regnat escriuen en llengua catalana, com ara l'autor del Curial. D'altra banda, l'autor d'aquell poema, Pujol, només pretenia, segons confessa, narrar «vera història», front a l'autor del Curial, que manifesta fer una obra vera de ficció, la qual defensa per tots cantons que és ajustada a la realitat. Insisteixo: amb tots els matisos de diferenciacions, ens movem en un mateix ambient historicoliterari.

Posarem ara l'atenció en els dos passatges a què ens hem anat referint -el pròleg del III llibre i el somni del Parnàs -, 27 ja que afecten especialment la conjunció citada. I ho faig amb el text de la introducció que a www.ivitra.ua.es acompanya la traducció que he fet de la novel $\cdot 1 a,{ }^{28}$ considerant que és positiu

25. Cal recordar el tema del retorn del Magnànim, cantat sobretot per la poesia; retorn demanat repetidament per les corts que ha arribat a fer del Curial una mena de consolació envers la reina Maria (Espadaler 1984).

26 El capítol: La historiografia catalana en el pas de Renaixement al Barroc: el poema èpic sobre Lepant de Joan Pujol (1573) conclou «que la clau per interpretar el poema de Lepant de Joan Pujol i de Lluís Joan Vileta podria ser...», ib. 570.

27 A l'edició del Curial que seguim, la d'Aramon, els textos es troben a les pp. 5-16 i 72-94.

${ }^{28}$ El to de la mateixa no és d'investigació ans de difusió. (M'excuso a l'avançada si hi ha alguna línia que repeteix algun concepte que hagi exposat en les línies precedents i suposi una redundància). 
pouar d'una exposició que no pertany a un enfocament particular ans a una lectura general, ja que ens situa en un marc sense predeterminació. Aquest text l'he redactat com una mena de passeig al llarg de la novel.la, tot acompanyant el lector, segons declaro al pròleg. Ens situem, doncs, a la passejada pel llibre III.

Para leer el libro III. Prólogo: Este prólogo es importantísimo para la obra entera por ofrecérsenos las claves de lectura, las cuales afectan más allá de este libro. Giran principalmente alrededor del talante del autor y sus ideas de teoría literaria, así como acerca del personaje Curial.

Comienza citando a las nueve Musas del Parnaso, de las que se hace mención en este libro - por lo tanto, nos orienta ya hacia la materia teórica señalada - y se relata la fábula ovidiana de las Metamorfosis (libro V), que narra cómo otras nueve hermanas, las Piérides o hijas de Pireo, desafiaron a las protegidas de Apolo, y cómo, al perder el pugilato, fueron convertidas por los dioses en urracas, que hablan todas las lenguas pero no saben lo que dicen. Poco después se remitirá a ellas el autor, diciendo que los hombres de poca ciencia deben callar ante los sabios, al igual que aquéllas ante las Musas, excusándose de emularlas al no haberse dedicado durante su vida a estos menesteres. Pues el autor aquí va a entrar en el terreno de las poéticas ficciones y de antemano confiesa que su estilo llano no es el propio de la alta literatura alegórica; con ello, aparte del humor crítico hacia ésta, a la que da un duro golpe, deja establecido las ideas que asentará en el sueño del Parnaso a favor de la escritura realista. Este es el criterio que, con el Decamerón de fondo, ha seguido a lo largo de toda la obra, por temas o fuentes nobles que tratara, que en este libro llegarán a las cimas de la literatura clásica. Es la rúbrica que impone un estilo real, vivo y desenfadado, en oposición y contraste con la literatura irreal y ampulosa del pasado, considerada artística o científica.

Hace también unas divertidas elucubraciones hacia la voz, que en realidad son una burla de la gramática tradicional, cosa que agradaba a los humanistas y que había hecho ya Valla (Voigt I, 468).

A pesar de ello - se dice-, algunos hombres de ciencia son soberbios y les ocurre lo que le ocurrió a Curial y ha ocurrido antes a los reyes Nabucodonosor y Ezequías, ${ }^{29}$ que fueron castigados hasta que se reconocieron a sí mismos. Y eso que Curial conocía estos hechos, como también sabía que los emperadores romanos llevaban en el carro triunfal a un esclavo que les recordaba que no debían ensoberbecerse. Ejemplos todos ellos reales - en el doble sentido de la palabra, regio y realista - que afectan a la personalidad del personaje si, como se sospecha, apunta a un monarca.

${ }^{29}$ Hay que observar que la mención del caso de este rey, que — como se explica aquí- se le quitaron 15 años de vida terrenal, pero se le restituyeron por su penitencia, es inmediata a la de Trajano en el Paraíso de la Divina Comedia (XX, vv. 43-54). Esto es muy significativo en un admirador de Dante como es este autor, dado que al emperador Trajano le saca san Gregorio del purgatorio, hecho similar a lo que en este libro va a hacerse con su personaje: sacarlo de su purgatorio mediante las palabras de este santo (Butinyà, Boccaccio y Dante en el «Curial y Güelfa», «Epos» VII [1991], 271-273). 
Curial, pues, que cae en la soberbia, es también castigado en este libro, sufriendo más que Job, ya que éste no perdió nunca su libertad.

Compara también a Curial con los grandes guerreros de la Antigüedad, diciendo que no fue su caso, pero que no les fue a la zaga en valor. ${ }^{30}$ Cierra con una fórmula jurídica de conclusión ${ }^{31} \mathrm{y}$, haciendo referencia a Tito Livio, Virgilio y Estacio, dice que si hubiera estado en sus manos la historia de Curial habría sido recordada y apreciada, dado que hubieran sabido dorar, con la ficción, los actos de plata; y si eran de oro, los hubieran sabido aumentar. ${ }^{32}$ Con ello, una vez más, se excusa por su estilo y limitaciones, pero de hecho deja a Curial presto a ser encumbrado, muy a pesar de los actos tan plateados que nos va a describir en este libro de purgación.

Su ideal de veracidad y llaneza son continuación de los criterios que había asentado Salutati y que mantenía Bruni, quien trataba de «glorificar al pueblo florentino, pero no con alabanzas retóricas», Garin 1982, p. 40. [...]

Curial en el Parnaso: Es éste un episodio central por transparentar el autor su teoría literaria, de gran transcendencia teniendo en cuenta que se trata de la primera obra de narrativa larga en prosa, donde fraguan las tendencias anteriores en un experimento literario de alta flexibilidad y, además, gran rentabilidad; es decir, la novela es un género abierto por antonomasia, pues se genera al calor de este principio (incluye diálogos, monólogos, sermones, canciones, etc.en una unidad superior), al igual que del realismo. Y esto está ocurriendo por primera vez en la literatura occidental. ${ }^{33}$ Por ello, hay que valorarlo al margen de que esta obra haya repercutido o no; el paso siguiente es el Tirant, tan parecido y con tantas posibilidades de conexión, ${ }^{34}$ si bien no se han documentado hasta el presente.

En la llegada de Curial a la acrópolis de Atenas hay que destacar varios hechos, pues el impacto de este lugar en el caballero va a ser muy resaltado, cosa que no ocurrió con los Santos Lugares. Nos fijamos en primer lugar en la

30) Cabe recordar aquí que el Magnánimo era frecuentemente comparado a los romanos (Voigt I, 493), al igual que a Héctor y a Hércules, a quienes se compara seguidamente a Curial.

${ }^{31}$ Abundan estas expresiones en la obra, lo que ha dado pie a menudo a pensar que el autor es un jurista (como lo era el notario mosén Gras).

32 La idea de que la memoria de los actos radica sobre todo en contar con buenos escritores, que ya pronunciara el Ceremonioso en 1380 con frase de Salustio, al donar su biblioteca, pudo haber marcado las letras catalanas ya que no es la única vez que aparece. Es además idea que se enarbola en el humanismo, como recoge Garin (1986, 83-84) de Poggio Bracciolini. Y por último, cabe recordar que era un tópico referido al Magnánimo, que aparece hasta en poema de Ausiàs March, el hecho de que no contaba con buenos biógrafos.

${ }^{33}$ Hay que dejar de lado la literatura clásica ya que no incide directamente en este nuevo género; aunque influye en Boccaccio, por ejemplo en técnicas como la del enmarcado, el certaldés en rigor no cultivó lo que denominamos novela sino la narrativa breve.

${ }^{34}$ Desde el planteamiento de que la obra sea napolitana, Martorell estuvo muy relacionado con esta corte, personalmente y por medio de parientes; por otro lado, en cuanto a la hipótesis de Gras, Riquer cree que el fragmento de la Mort Artu que reproduce el Tirant procede de la traducción de éste, de La tragèdia de Lançalot, de la que aquél es autor (Tirant lo Blanch, novela de historia y de ficción, ed. Sirmio, Barcelona, 1992, 79). 
referencia y recuerdo de la Tebaida, aludiendo al fin de esos hechos trágicos con su visita a los sepulcros de los hermanos; lo cual puede tener un efecto amenazador o, por lo menos, de advertencia y recuerdo. Pero sobre todo, como científico y amante del estudio, le interesa la ciudad que dió leyes a Roma y el «studi famós» en el que se aprendía la ciencia de conocer a Dios; es decir, que se estudiaba la filosofía, antes equivalente a la teología. ${ }^{35}$

La impresión es tanta al llegar al Partenón que sus compañeros, atemorizados, se ven forzados a sentarse. Curial avanza un poco más, pero finalmente se ve obligado también a tomar asiento en un escalón de mármol y, reclinando la cabeza en una piedra, se duerme. El autor, pues, ha dibujado la escena que va a envolver el sueño del Parnaso como lo haría un pintor renacentista, lleno de veneración hacia la Antigüedad.

En sueños ve a Héctor y el pavor que tiene es tal que - según una comparación clasicista que recoge Justino-, si su madre, Honorada, hubiera estado allí le hubiera tenido que dar apoyo moral. ${ }^{36}$

Empieza a continuación un apóstrofe, en el que se dirige al libro -al estilo de los clásicos-, el cual encierra ideas claves acerca de la intencionalidad de la obra: el autor dice que experimenta un rechazo, dado lo increíble de lo que va a contar, y cita los versos de Dante ante la misma sensación (Infierno XVI, vv. 124-126). Pero se ve obligado a contarlo al haberle alegado en su texto el Somnium Scipionis; ahora bien, ¿y el sueño del Faraón que moralizó Jean de Limoges? ${ }^{37}$ Hace luego una divagación sobre el valor de los sueños, tan discutido en su tiempo, como bien muestra otra obra muy cercana, a cuya luz se puede iluminar también todo este pasaje, la Comedieta de Ponça. Acaba diciendo que el libro - tú, en toda esta alocución- va a contar los sueños y él va a recitar lo que se ha publicado ya, según la información que ha recogido. nista.

35. He aquí una fina disección de lo religioso y lo filosófico muy propia de la corriente huma-

${ }^{36}$ Estas madres persas, según el reconocimiento que hizo Rosa Lida de Malkiel, ayudaban a sus hijos a superar el miedo volviéndoles a mandar a la batalla. Luego, nos hallamos ante un recuerdo maternal dignificado, al igual que comentamos que ocurría en el relato decameroniano que se está proyectando desde el principio de este libro III (Tras los origenes del Humanismo: el «Curial e Güelfa», o. cit., 281-282). Ello tiene importancia si, como también dijimos, asimismo está presente el recuerdo de la Comedieta de Ponça, pues en la obra castellana, panegírica, se desfiguran los hechos en relación a la madre del Magnánimo; por ejemplo, se dice ahí que murió a consecuencia del disgusto de la batalla, lo cual era una falsedad. (Interesa al respecto todo el apartado 3.1.3.3. en ib.). El tono general del juicio del Parnaso - de alabanza de un estilo culturalista y elevado, pero con reproches hacia su historicidad- es idóneo también hacia la obra del marqués de Santillana. excelsa pero desfiguradora de los hechos reales.

${ }^{37}$ El hecho de leer el texto con esta interrogación, según una fórmula no extraña en el Curial, puede dar la clave del pasaje: en la novela se incluye al final el Somnium Scipionis, que se refiere al premio de la vida futura a la virtud, pero primero hay que tener en cuenta la rectificación, arrepentimiento o buen comportamiento; cosa que hacía el texto de Jean de Limoges sobre los sueños del faraón. En esta obrita sin importancia, que no tiene ningún sentido incluir aquí de otro modo, se reprendía al rey por sus pecados contra la moralidad (Tras los orígenes del Humanismo..., o. cit., 144-149). 
Curial ve seguidamente a las Musas, que daban ánimos nada menos que a Homero. Una de ellas se presenta en nombre de todas y le explica que ha sido elegido para juzgar el caso de Homero, autor de la Aquileida ${ }^{38}$ Los acusadores son Dictes y Dares, que habían escrito sobre los mismos hechos con documentación; sin embargo, por boca de Homero «se dix tot ço que dir se podia per la lengua grega». No puede haber mayor alabanza de su estilo; ahora bien, es acusado por haber desfigurado los hechos a favor de Aquiles, en perjuicio de Héctor.

El tono, entre solemne y burlesco, remite al lector al prólogo, en que el autor se consideraba indigno de la materia de este libro por no haber seguido a las Musas desde su juventud, pues Curial se manifiesta indigno de codearse con aquellas nueve hermanas, que hacen compañía a los mayores autores del clasicismo. Calíope precisamente arguye aquí que ellas están acompañando a Homero, quien en vida las tuvo siempre a su lado; Curial recela en cuanto a su capacidad de juzgar sobre lo que no ha visto, pero la Musa le declara que le serán reveladas las cosas como si hubieran ocurrido en su presencia.

Curial entonces recibe una mitológica iluminación del sol y ve cómo se le inclinan reverencialmente los laureles. ${ }^{39}$

El juicio de Curial: Curial se instala en el consistorio con dignidad de juez y a continuación Homero llama a Aquiles, pidiéndole su intercesión, dado que el autor en vida le favoreció y su opinión la han seguido autores como Virgilio; pero ahora - le explica - los acusadores discuten si en realidad no fue mejor Héctor y si él le venció dignamente. ${ }^{40}$

Pero cuando Aquiles va a intervenir encendidamente, es interrumpido por Apolo, quien dice que su momento ya ha pasado y que él conoce bien la verdad de los hechos.

Se describe a Aquiles con detalle de cualidades y, entre los defectos, se dice que es lujurioso y, como dice la Fiorita - sin lugar a dudas respecto a la fuente, asegura - también, mentiroso y falso. De nuevo, pues, nos hallamos

${ }^{38}$ Esto es una broma y no un error, pues es normal este sufijo para indicar que se habla en honor o repetidamente de aquello (Eneida, Tebaida...), que es lo que hizo Homero respecto a Aquiles, según se va a dirimir a continuación.

${ }^{39}$ Sea el hecho de la laurea, sea la asimilación del autor con la figura de Marsias, este sueño haIla una excelente explicación en el capítulo XI de E. Wind, El desollamiento de Marsias, en Los misterios paganos del Renacimiento (Barral ed., Barcelona 1972, 173-177); hay que tener presente que esta novela es una nobilísima reprensión y que el autor hace el papel del sátiro: en su obra el caballero se convierte por medio del dios $\mathrm{Baco}$, tras haber oído la máxima délfica del autoconocimiento repetidamente de boca de su mentor, al que la crítica ha identificado con el novelista. De hecho, es un ejemplo de teología poética, del mismo modo que la pinta Rafael en el cuadro de aquel desollamiento y se explica en el capítulo citado de Wind.

${ }^{40}$ Hay que observar el juego entre los diversos libros y que esta problemática de la escritura verídica afecta a toda la novela. En el II se encendió la polémica sobre la misma cuestión del valor de Aquiles, dejando constancia de que al cabo de los siglos todavía estaba viva; por tanto, se constata una vez más que la fama, en manos de las escritores, o la repercusión literaria es algo muy importante. 
ante una broma literaria, pues este dato no consta en esa obra de Armanino de Bolonia, que recoge leyendas e informaciones deformadas; por lo tanto, una vez más, se están dando notas — jocosa ésta - en torno al tema de la deformación literaria.

En pleno esplendor mitológico son coronados de laurel Homero y Aquiles. A continuación vienen Dictes y Dares, «solemnes historials e poetes» y, acompañados por Héctor, ponen en manos de Curial los libros que tratan de aquél, según relata Guido de Colonna. ${ }^{41}$

La descripción de Héctor presenta un blanco en el manuscrito. Curial tiembla ante él por impresión moral; además, hay una gran desproporción en tamaño entre ambos - a pesar de que Curial es bastante normal entre los hombres de su tiempo-_, ${ }^{42}$ si bien queda claro que también le horroriza la diferencia y altura moral.

Apolo hace que se separen Héctor y Curial, pues va a informar a éste de la realidad; ante lo cual aquél aclara que no desea loas vanas. Entonces, Apolo llama a Homero a su presencia y le reprende por haber escrito teniendo en cuenta su gloria por encima de la verdad de los hechos. Y, para ese resultado, él no le había confiado las Musas; puesto que, de este modo, con su estilo maravilloso ha convencido a todos de cosas que no son reales. Igualmente hizo Virgilio, de quien explica el caso de Dido falseado, dado que no coincidió en el tiempo con Eneas; al igual que no ofendió la memoria de su marido, como bien había advertido san Jerónimo. ${ }^{43}$ La frase que resume la exposición del dios del Parnaso es: «Bo és poetar; mas contra veritat escriure, no·m par sie loor».

Apolo entonces corona a Curial de laurel como el mejor caballero y como el mejor poeta y orador de su tiempo; lo cual, en este ínclito entorno es una burla que hace reflexionar en el caso de que Curial represente a alguien. ${ }^{44}$ O bien - también cabe añadir esta interpretación - el autor, entre bromas y veras, está consagrando en esta obra el futuro de su estilo literario; cosa que da mucho que pensar a la vista del triunfo del género de la novela.

El pronunciamiento final de Curial es fiel a las palabras de Apolo, pero es ecléctico, dado que reconoce el mérito de todos: el de los dos combatientes, el del libro de Homero, así como también el que Dictes y Dares escribieran la verdad. ${ }^{45}$

4) Sobre esta obra puede verse Tras los origenes del Humanismo.., o. cit., 159-176, donde se explica que su relevancia no supone una adscripción a una literatura menos excelsa; es decir, no se trata de la defensa de un criterio medievalizante, sino de las maneras de escribir respecto a la veracidad, dado que en esta época se exige más que en épocas anteriores.

42 De nuevo se incluiría aquí, al parecer, una broma hacia el Magnánimo, por su pequeña estatura.

4.7 Cabe recordar que Petrarca también se había fijado en este hecho y en las Seniles deshacía ya el entuerto.

44 Hay que tener en cuenta que, en La Comedieta de Ponça, el Magnánimo - que componía poesías - aparecía coronado de laurel, cosa a la que podía una vez más estar contraponiéndose el autor en esa obra, tan amante de la exactitud.

${ }^{45}$ Tanta preparación para abocar a este prodigio de eclecticismo deja de nuevo retratado al tan equilibrado autor. Una reflexión parecida se puede desprender de toda la novela, la cual, a pesar de 
Como colofón a este importante pasaje hay que decir que si en los pasajes principales hemos sugerido la asimilación por parte del autor de los planteamientos de Aristóteles (Tras los origenes del Humanismo, o. cit., 112 ss., 187 ss., 353 ss.), aquí, lo ratificaríamos en cuanto a teoría literaria, pues la literatura, y en especial la poesía, se defiende como filosóficamente cierta.

Pero hay que tener en cuenta que no se trata sólo de realismo literario sino de veracidad; y como la obra está bajo estos parámetros, es importante el reflejo de la realidad o las identificaciones o paralelismo con hechos reales, que no son meramente un juego, pues están en ese quicio entre la ficción y la realidad, que se está gestando entonces y que dará paso a la novela moderna. Muy próximo a los cánones que asentara Bruni como historiador (Garin 1982, p. 40) pero bajo la égida de la creación literaria; cercano, pues, también a Metge, quien en un diálogo de ambición estética y de alta elocuencia había dejado una obra filosófica muy valiosa, Lo somni, en el ámbito de la ficción.

Los compañeros de Curial lo despiertan: Los compañeros de Curial, que habían perdido el mundo de vista, se recuperan muy aliviados; ven entonces extrañados que el caballero está coronado de laurel. Al despertarlo, él se toca la corona, así como ve inscrito en su frente la explicación correspondiente a ese honor en un cartel, y deduce que aquéllos se habían burlado de él; pero ellos lo niegan, pues además aquellos signos no eran propios de manos humanas. ${ }^{46}$ Curial queda por todo ello fuertemente impactado. Embarca, luego, y manda emprender rumbo a Génova.

Així doncs, no es tracta sols de realisme literari ans de veracitat; i com que l'obra es troba tota ella sota aquests paràmetres - àdhuc els passatges al-legòrics, farcits d'ironies i referències al món real, més enllà del de la ficció estricta-, cau de ple a la cruilla de la ficció i la realitat, on justament s'està gestant la novel-la moderna, ${ }^{47}$ que esplèndidament va definir Riquer per a la novel-la cavalleresca (1964: 575-601). ${ }^{48}$ I això és així fins al punt que la clau realitat-ficció

su insistencia en precisar la casuística amorosa, por la virtud que actualmente nos sorprende es por esta perspectiva de objetividad, de voluntad armonizadora, persistente desde todos los ángulos y tan peculiar de los primeros humanistas.

46 Una obra que defiende el realismo tiene que jugar con este costado de la ficción, que se presenta como realidad; de modo parecido, en el Tirant, algunas escenas que parecen increíbles o fictas, acaban con el contraste más realista, por ejemplo, con un remojón o algo por el estilo.

47 Malgrat tot aquest conjunt de coses, els historiadors comencen a tenir en compte o citar el $T_{i}$ rant o àdhuc March, però el Curial, molt més proper a la història, per la seva retòrica i declaracions, ni s'apropen; i encara que una obra anònima caigui en el terreny de les hipòtesis, cal recordar que aquestes són una eina científica, que permet de bastir teories - i això a filologia i a història-, com ara en certa manera estem fent amb els orígens de la narrativa, contrastant una hipòtesi d'autoria concreta. Cal recordar que de fet és el propòsit de l'estudi de Duran, segons les contracobertes: «Situar la literatura i les discussions intel-lectuals del l'època en aquest context il-lumina aspectes desconeguts en la creació i difusió de les millors obres literàries del Renaixement català». (Vegeu la nota 7 supra).

${ }^{46}$ En un intent de reconstrucció de l'humanisme hispànic potser podríem veure la petja d'aquesta historiografia humanística com a factor que individualitza el gènere de la novel-la cavalleresca, 
dóna peu per a entendre obres renaixentistes anònimes, com ara Qüestión de amor, del 1513, ja que tant la història com la ficció distorsionen els fets: «Fins i tot podem trobar que una 'història' pot ser més fictícia, perquè està al servei d'uns interessos als quals serveix, que no la ficció, més lliure en la seva intencionalitat» (Duran, 650), ${ }^{49}$ la qual cosa és l'altra cara de la moneda del que Riquer deia dels textos cavallerescos: que eren més ajustats a la realitat que les cròniques dels mateixos fets.

La novel·la, imparable com a troballa literària, com a gènere culte, didàctic i plaent, anirà estenent-se, entre literats i historiadors, a filòsofs o teòlegs. Un dels aspectes que copsen d'aquest matrimoni historicoliterari primitiu és la inclusió per part de Centelles, en la seva traducció de la biografia alfonsina del Panormita, de dues novel-les (Duran, 598-599), que tracten d'actes de justícia del Magnànim; ${ }^{50}$ precisament la segona coincideix amb una cançó que presenta connexions històriques i interferències amb el Novellino (Duran, 605) i amb una cançó del Monferrat. I si tenim en compte que el Curial aprofita aquest recull italià i és situat al Monferrat, tot i que sense mirar les possibles implicacions concretes envers el Panormita i el seu biografiat, se'ns fa la novel-la molt propera a aquells fets.

Una obra com el Curial pot respondre al que demanaven els humanistes quan teoritzaven al voltant de la història amb l'ajut de la ficció poètica. Val a dir: una obra artística tan autèntica com si fos realitat i tan productiva com la història.

Hi ha diferents opinions per tal d'assenyalar el punt de partença de la narrativa occidental moderna, ${ }^{51}$ però sembla que no es pot deixar de tenir en compte, quant als orígens, la renovació dels gèneres que assenyala l'Humanisme. ${ }^{52}$ Senzillament, com un fruit madur de les discussions i un pas endavant, des de les realitzacions i criteris de Boccaccio i Petrarca, que ja eren conscients de la

front a les realitzacions en llengua castellana, més idealistes i fantasioses però dins també de la creació literària de la cavalleria. Perquè en realitat a totes dues literatures els arriba al mateix temps la sedimentació de la prosa (Gómez Redondo, La Prosa del Siglo XIV, en Historia de la Literatura Española, 7, ed. de R. de la Fuente, ed. Júcar, Madrid).

${ }^{49}$ En bona lògica les relacions històriques s'aprofiten també - així com al meu estudi-per a establir-hi hipòtesis d'autoria, Duran, o. cit. 627.

50) Podríem anotar que la conversió de Curial per mitjà de paraules de sant Gregori sembla ser rèplica de la llegendària conversió de Trajà que recull la Divina Comèdia, tot referint-se a la seva justícia (vegeu les notes 21 i 29 supra).

${ }^{51}$ Deixem de banda la novel-la en vers (Chrétien de Troyes) i la narrativa breu o estrictament sentimental (Boccaccio), ja que no presenten alguns trets, sempre relatius però que semblen avui fundamentals: la prosa, la durada, la multiplicitat (obertura o flexibilitat).

${ }_{52}$ No donem cap definició de l'Humanisme, perquè sempre és un aspecte discutit però tothom entén el que és aquest moviment; així, remetem a aquesta entesa i el que designa comunament, deixant les visions restrictives i excloents (que no accepten una època determinada o una llengua). Bé que també es pot veure com el primer moment del Renaixement, com fa Duran (2004: 381), qui considera que es «la primera manifestació del Renaixement pel que representa de revaloració del món clàssic grec i romà», la qual, junt amb l'aristotelisme i el neoplatonisme conforma el pensament renaixentista. 
importància de la historiografia antiga (Voigt, II, 479 passim). I si això afecta a altres gèneres, afecta també a la novel-la, encara més legitimada pel fet de no remuntar-se al classicisme; ${ }^{53}$ és a dir, per tenir una pròpia embranzida, un nou pedigree.

Farem la cloenda amb unes paraules de Jeroni Miguel (2004) sobre aquesta cort napolitana i sobre el punt referent a la historiografia: «Fueron, sin embargo, los humanistas que residieron permanentemente en la corte - los escritores aúlicos-, o pasaron largas temporadas en ella, los que recibieron la mayor atención y protección por parte del Magnánimo. Y es la historiografía el género que más interesa, por ser la disciplina que contribuyó a difundir la imagen del rey sabio, liberal y protector de los hombres de letras. Conviene destacar que la historia era una disciplina humanística, y en los círculos cortesanos se suscitaba la polémica en torno a su esencia y método utilizado. En lo que sí estaban todos de acuerdo, era en la definición que Cicerón había ofrecido en su De oratore: "La historia es testimonio de los tiempos, luz de la verdad, vida de la memoria, maestra de la vida, mensajera de la antigüedad". Era criterio común que había que respetar estos principios para no privar a la historia de su indispensable carácter de objetividad. Ocurría, no obstante, que, al ser una disciplina ligada a la oratoria, los recursos de ésta servían de excusa para exaltar en exceso los hechos narrados de los protagonistas. No hay que olvidar que los historiadores, en general, conocían muy bien esta materia y presentaban de forma convincente los hechos. Ello, consecuentemente, hacía que los príncipes vieran en los historiógrafos los artífices de su fama y el modo más directo para que sus hazañas pasaran a la posteridad.»

\section{BIBLIOGRAFIA}

ARAmON I SERRA, R. (1930-1933) (ed.): Curial e Güelfa, «Els Nostres Clàssics», ed. Barcino, 1930-1933, 3 vols.

BATLloRI, M. (1995): Obra completa, V, De l'Humanisme i del Renaixement, ed. Tres i Quatre, València.

Beccadelli, El Panormita (1990): Dels fets e dits del gran rey Alfonso, a càrrec d'E. Duran, «Els Nostres Clàssics», ed.Barcino, Barcelona.

BUTINYÀ, J. (2001): Tras los orígenes del Humanismo: El «Curial e Güelfa», UNED, Madrid 2001 ${ }^{3}$. Es pot consultar en www.uned.es/453196.

ButinYÀ, J. (2002a): En los orígenes del Humanismo: Bernat Metge, UNED, Madrid. Es pot consultar en www.uned.es/453196.

ButinYÀ, J. (2002b): Del Griselda català al castellà, «Minor» 7, Reial Acadèmia de Bones Lletres de Barcelona. Es pot consultar en www.uned.es/453196.

Butinyà, J. (2002c): Barcelona, Nápoles y Valencia: tres momentos del Humanismo en la Corona de Aragón, en Historia y poética de la ciudad. Estudio sobre las ciuda-

53. Al meu parer, aquesta explicació és prou per entendre com apareix aquest gènere narratiu al marge de la novel-la clàssica: li era suficient la historiografia. 
des de la Península Ibérica, «Revista de Filología Románica» III, coord. per E. Popeanga i B. Fraticelli, 81-98.

BUTINYÀ, J. (2004a): La recepción del Humanismo (del siglo XIV al XV); Bernat Metge: el diálogo de "Lo somni», La primera novela caballeresca: el «Curial e Güelfa», en www.Liceus.com.

BUTINYÀ, J. (2004b) trad. i intr. de: Lo somni de Bernat Metge i del Curial e Güelfa, en www.ivitra.ua.es.

BUTINYÀ, J. (2004c): Sobre el Humanismo catalán y las periodizaciones, «Revista de Lenguas y Literaturas Catalana, Gallega y Vasca», vol. IX, 251-278.

BUTINYÀ, J. (2005): El Humanismo catalán, en «eHumanista» 5, en www.spanport.ucsb. edu/projects/ehumanista/.

DURÁN, E. (2004): Estudis sobre la cultura catalana al Renaixement, ed. 3 i 4, València.

ESPADALER, A. (1984): Una reina per a Curial, ed.Quaderns Crema, Barcelona.

GARIN, E. (1982): Ciencia y vida civil en el Renacimiento, ed. Taurus, Madrid.

GARIN, E. (1986): El Renacimiento italiano, ed. Ariel, Barcelona.

Miguel, J. (2004): La corte napolitana del Magnánimo. Jordi de Sant Jordi, en www.Liceus.com.

RiqueR, M. DE (1964): Història de la Literatura Catalana, II, ed. Ariel, Barcelona. 